\title{
Arthropods of the great indoors: Characterizing diversity inside urban and suburban homes
}

Matthew A Bertone, Misha Leong, Keith M Bayless, Tara L. F. Malow, Robert R Dunn, Michelle D Trautwein

Although humans and arthropods have been living and evolving together for all of our history, we know very little about the arthropods we share our homes with apart from major pest groups. Here we surveyed, for the first time, the complete arthropod fauna of the indoor biome in 50 houses (located in and around Raleigh, North Carolina, USA). We discovered high diversity, with a conservative estimate range of 32 to 211 morphospecies, and 24 to 128 distinct arthropod families per house. The majority of this indoor diversity $(73 \%)$ was made up of true flies (Diptera), spiders (Araneae), beetles (Coleoptera), and wasps and kin (Hymenoptera, especially ants: Formicidae). Much of the arthropod diversity within houses did not consist of synanthropic species, but instead included arthropods that were filtered from the surrounding landscape. As such, common pest species were found less frequently than benign species. Some of the most frequently found arthropods in houses, such as gall midges (Cecidomyiidae) and book lice (Liposcelididae), are unfamiliar to the general public despite their ubiquity. These findings present a new understanding of the diversity, prevalence, and distribution of the arthropods in our daily lives. Considering their impact as household pests, disease vectors, generators of allergens, and facilitators of the indoor microbiome, advancing our knowledge of the ecology and evolution of arthropods in homes has major economic and human health implications. 
1 Arthropods of the great indoors: Characterizing diversity inside urban and suburban

2 homes

3

4 Matthew A. Bertone ${ }^{1}$, Misha Leong ${ }^{2}$, Keith M. Bayless ${ }^{1}$, Tara F. Malow ${ }^{3}$, Robert R. Dunn ${ }^{4}$, and

5 Michelle D. Trautwein ${ }^{2}$

6

7 1- Department of Entomology, North Carolina State University, Raleigh, NC, USA

82 - California Academy of Sciences, San Francisco, CA, USA

93 - North Carolina Museum of Natural Sciences, Raleigh, NC, USA

104 - Department of Biological Sciences, North Carolina State University, Raleigh, NC, USA 


\section{ABSTRACT}

Although humans and arthropods have been living and evolving together for all of our

history, we know very little about the arthropods we share our homes with apart from major pest groups. Here we surveyed, for the first time, the complete arthropod fauna of the indoor biome in 50 houses (located in and around Raleigh, North Carolina, USA). We discovered high diversity, with a conservative estimate range of 32 to 211 morphospecies, and 24 to 128 distinct arthropod families per house. The majority of this indoor diversity (73\%) was made up of true flies (Diptera), spiders (Araneae), beetles (Coleoptera), and wasps and kin (Hymenoptera, especially ants: Formicidae). Much of the arthropod diversity within houses did not consist of synanthropic species, but instead included arthropods that were filtered from the surrounding landscape. As such, common pest species were found less frequently than benign species. Some of the most frequently found arthropods in houses, such as gall midges (Cecidomyiidae) and book lice (Liposcelididae), are unfamiliar to the general public despite their ubiquity. These findings present a new understanding of the diversity, prevalence, and distribution of the arthropods in our daily lives. Considering their impact as household pests, disease vectors, generators of allergens, and facilitators of the indoor microbiome, advancing our knowledge of the ecology and evolution of arthropods in homes has major economic and human health implications. 


\section{INTRODUCTION}

For as long as humans have lived in fixed habitations there have been other organisms that dwell alongside us. We share our living spaces with a variety of invited and uninvited guests spanning the tree of life, from large vertebrates (e.g., pets and livestock) to microorganisms (Martin et al., 2015). The most diverse and abundant group of multicellular life found in homes, as well as on Earth more generally, is represented by arthropods.

Insects, spiders and their relatives have been living and evolving with humans for all of our history. It has been proposed that many arthropod species that are now associated with human houses were originally cave dwellers (e.g., bed bugs: Cimicidae) (Balvín et al., 2012). Evidence of arthropod vectors in caves inhabited by prehistoric people ca. 26,000 years ago suggests that pestiferous arthropods, such as blood-feeding kissing bugs (Reduviidae: Triatominae), lived alongside our ancestors (Araújo et al., 2009). Among the first examples of cave art is a depiction of a camel cricket (Rhaphidophoridae) (Chopard, 1928; Belles, 1997). As human society changed over time, arthropods successfully -- and rapidly -- made use of our bodies and resources for food and shelter. Constructed houses, animal domestication, agriculture and the ability to store food (such as grains) brought different arthropod species into the domiciles and daily lives of humans. Arthropods are common fauna in domestic archaeological sites from Egypt (dating as far back at 1353 B.C.E), Israel, and Europe (Switzerland, Greenland, and the UK) (Nielsen et al., 2000; Panagiotakopulu, 2001; Panagiotakopulu, 2003; Kislev, Hartmann \& Galili, 2004; Panagiotakopulu, 2004; Kenward \& Carrott, 2006), with some species characteristic of stored food products and livestock, and others representative of local fauna. 
perceived of as being an environment largely devoid of animal life. However, arthropods thrive in homes, as evidenced by today's multi-billion dollar pest control industry. Houses today host many of the same pest groups found in archeological sites (see Results), yet today's arthropod communities also reflect aspects of society's modernization. For example, with the advent of indoor plumbing, dung beetles (Scarabaeidae) are less prevalent indoors (as shown in this study), but drain-dwelling moth flies (Psychodidae) are likely more so. Also, as human society became more globalized through travel and trade, arthropod species that are closely associated with humans and their homes, such as the house fly (Musca domestica L.; Legner \& McCoy, 1966),

German cockroach (Blattella germanica L.), and fruit fly (or vinegar fly, Drosophila melanogaster Meigen; Keller, 2007) obtained worldwide distributions and, in some cases, even lack wild populations (e.g. the German cockroach; Roth, 1985; Booth et al., 2010). The influence comprehensive survey of arthropod life in contemporary human houses has never before been carried out. 
A systematic sampling of the complete arthropod fauna in the interior of homes and an

8

understanding of the role that interior microhabitats play in determining the assemblage of arthropod communities are the first steps toward revealing ecological dynamics in a vastly understudied system (Baz \& Monserrat, 1999; Dunn et al., 2013). What are the most prevalent arthropod groups found in houses and how common are they among homes and rooms? Here we explored the composition of overall arthropod diversity, including both pest and non-pest species, in human dwellings. Through surveying 50 free-standing houses located in the North Carolina Piedmont region, we identified and characterized the overall diversity of arthropods found within these homes.

\section{MATERIALS \& METHODS}

We solicited volunteers owning or renting free-standing homes in Raleigh and neighboring areas of North Carolina, USA. The study area is located in the Piedmont of the state and characterized by red clay soils and deciduous/pine forests (with meadows and aquatic/semiaquatic systems interspersed) among various urban and suburban development (Fig. 1). We randomly selected 50 homes/volunteers to visit from among participants who filled out an online questionnaire about the characteristics of their household and behavior of its residents. All homes included in the study were within a 30 mile radius of Raleigh's center $\left(35.7719^{\circ} \mathrm{N}, 78.6389^{\circ}\right.$ W). Each home was visited once between May and October 2012. Upon arrival, volunteers were informed of the procedures and process for sampling arthropods and asked to sign a consent form (Supplement 1).

General Arthropod Sampling: 

specimens by hand using forceps, aspirators and entomological nets. Only visible surfaces, including those accessible under and behind furniture, around baseboards, ceilings, and on shelves and other surfaces were sampled. We collected all arthropods or putative arthropods, including those from spider webs; both living and dead arthropods were collected in this manner into vials containing $95 \%$ ethanol. We did not collect all specimens of a given arthropod species. We designated each distinct room or area and labeled its vial with the room name (as best identified), floor type, and number of windows and doors to the outside of the house; doors between rooms were not quantified. We identified floor types as wood (including laminates, hardwoods, and other wood-like surfaces), linoleum (tiles or otherwise), tile (stone, concrete, or

110 otherwise; not including linoleum) or carpet. The presence of small or large rugs on other

111 surfaces was noted as well. Typical room categories included kitchens, bedrooms (sometimes

112 specified as offices/dens because of their lack of running water, but not receiving the same 113 amount of traffic as common areas), bathrooms, laundry/utility rooms (denoted when a washer 114 and dryer were present), and common areas. Common areas consisted of large open areas that 115 were not easily categorized, usually including dining rooms, living rooms, front rooms, hallways, etc. Closets were sampled and included with the room in which they opened. When a room was

117 present on a floor other than the first/main floor, house level was recorded (e.g., "2nd Floor 118 Bathroom"). All rooms inside the house were sampled in the manner described above except for 119 attics and crawl spaces, which were sampled less thoroughly: only the entrance of each was sampled within a $2 \mathrm{~m}$ radius. The limited sampling method for these areas was deemed necessary

121 for the safety of those collecting the specimens (i.e. to avoid high summer temperatures in attics 
122 and confined areas in crawl spaces). Screened porches, decks, garages, detached sheds/structures,

123 and closets accessible only from the outside were not sampled.

124

125 Dust Mites:

126 We sampled dust mites from the middle of the master bedroom floor, regardless of floor

127 type, in a $0.5 \mathrm{~m}^{2}$ area. To collect mites, we used a vacuum that was adapted to use specimen cups

128 modified with a screen bottom composed of mesh with 0.0055 inch $(0.1397 \mathrm{~mm})$ openings, small

129 enough to allow air to pass through but not mites. We stored all samples in $95 \%$ ethanol until

130 they were sorted and quantified. Because of time and specimen handling constraints, only five

131 individuals from five randomly-selected samples were identified.

132

Identification and Classification:

We identified all specimens to family level except when specimens were badly damaged or required additional methods for identification (e.g., slide mounting of mites and other taxa).

We further determined genera and species when possible, but many specimens could not be identified to such a level for several reasons including, but not limited to, being damaged, being an unidentifiable sex (e.g., female Sciaridae) or an unidentifiable life stage (e.g., larvae), or being a group that is understudied or lacking good diagnostic keys. As such, our approach produced a very conservative list of morphotaxa for each room in the house and hereafter we call these morphospecies; this type of characterization has been found to be effective in comparing species richness and turnover between sites (Oliver and Beattie, 2002). The taxonomic identity of morphospecies was not compared between rooms within homes due to limitations on time, space

144 (storage of voucher specimens) and diagnostic expertise, thus the true number of morphospecies 
145 per house and among all houses was not definitively determined. Thus, a conservative (or

146 assumed minimum) estimate of morphospecies richness per house was created by taking the

147 maximum number of morphospecies from the room containing the highest number of

148 morphospecies, for each family, and summing the total. This is in contrast to a maximum

149 estimate of morphospecies richness which was the total sum of all morphospecies from all rooms

150 within a house; this maximum corresponds to the case in which no two rooms held the same

151 morphospecies. We assume the true diversity falls between our minimum and maximum

152 estimates. All voucher specimens are housed in vials of ethanol in the laboratory of RRD

153 (Department of Biological Sciences, NCSU) for use in further ecological, genetic, and

154 microbiological studies. Specimens will be deposited in the insect museum at NCSU

155 (Department of Entomology) when permanently housed.

156

157 Analyses:

158 We classified rooms into 6 categories based on their similarities of features and use:

159 attics, basements (including finished and unfinished basements, and crawl spaces), bathrooms

160 (including bathrooms and laundry rooms), bedrooms (including bedrooms, offices, and libraries),

161 common rooms (including living rooms, dining rooms, and attached hallways), and kitchens

162 (including kitchens and pantries); rooms not conforming to one of the categories were classified

163 as "other" and were excluded from Table 1 . We calculated an accumulation curve based on the

164 complete list of families acquired over each sampled house using the Chao2 Estimator with 1000

165 randomization runs in EstimateS (Colwell, 2013). We compared total dust mite abundance in

166 each sample with the floor type on which it was collected. Some samples were collected on

167 carpet, while others were on bare surfaces. Because the data were not normally distributed, we 
168 analyzed the differences between samples with different floor types using a Kruskal-Wallis test.

169 All analyses were done in R 3.1.2 (R Development Core Team, 2014).

170

171 RESULTS

172

Overall Metrics

173

Houses in the study ranged from 840 to 4,833 square feet in (mean $=2,072$; median $=$

$1,720)$ and were from seven to 94 years old $($ mean $=41.35$; median $=30.5)$. During the course of sampling 554 rooms in the 50 homes, over 10,000 specimens were collected and identified.

176

177

178

179

180

181

182

183

184 185

186

187 188

189 190

These specimens represented all four subphyla (Chelicerata, Myriapoda, "Crustacea", and

Hexapoda), as well as 6 classes, 34 orders and 304 families of arthropods (Table 1; Supplemental Table 1). While we cannot determine the exact number of morphospecies that were collected, there were at least 579 morphospecies based on our most conservative estimates (calculated by summing the maximum number of morphospecies for each family ever found in a single room). We collected 24 to 128 families from each house, resulting in an average of 61.84 (s.d. $=$ 23.24) distinct arthropod families per house and a total gamma diversity (across houses) of 304 families (Fig. 2). One hundred and forty-nine (149) families were rare, collected from fewer than $10 \%$ of homes, 66 of which were found in just a single home. The number of families collected in a home was correlated with house size $\left(r^{2}=0.3, \mathrm{p}=<0.001\right)$. Conservative species estimates by home ranged from 32 to 211 , with an average of $93.14($ s.d. $=42.34)$ morphospecies per house (Fig. 3). Considering that our conservative species estimate assumes that rooms with the greatest number of morphospecies by family included all species from other rooms (which is almost certainly untrue), this number is likely much lower than the true number of species per house (Fig. 3). 
Taxon specific observations

While overall diversity was high, 12 frequently found families were identified in at least $80 \%$ of homes (Fig. 4). Only four families were identified from $100 \%$ of houses sampled: cobweb spiders (Theridiidae), carpet beetles (Dermestidae), gall midge flies (Cecidomyiidae) and ants (Formicidae). Book lice (Liposcelididae) and dark-winged fungus gnats (Sciaridae) were found in $98 \%$ and $96 \%$ of homes, respectively. Nearly half of all families (five of 12) found in over $80 \%$ of homes were true flies (Diptera): fungus gnats (Sciaridae); mosquitoes (Culicidae); scuttle flies (Phoridae); non-biting midges (Chironomidae); and gall midges (Cecidomyiidae).

Typical household pests were found in a minority of the homes, such as German cockroaches (Blattella germanica: $6 \%$ of houses), subterranean termites (Rhinotermitidae: $28 \%$ of houses), and fleas (Pulicidae: 10\% of houses); bed bugs (Cimex lectularius Linnaeus) were not found during the study. Larger cockroaches (Blattidae), such as smoky brown (Periplaneta fuliginosa (Serville)) and American cockroaches (Periplaneta americana (Linnaeus)) were found in the majority of houses (74\%). However, the American cockroach (which is the only of the two considered a true pest) was only recovered from three homes; smoky brown cockroaches made up the vast majority of large cockroaches collected. All pest species were less common than other more inconspicuous arthropods such as pillbugs (Armadillidiidae, 78\%) and springtails

210 (Entomobryidae, 78\%).

In addition to those listed above, many of the same pests we recovered were also found in

212 archaeological sites (Nielsen et al., 2000; Panagiotakopulu, 2001; Panagiotakopulu, 2003;

213 Kislev, Hartmann \& Galili, 2004; Panagiotakopulu, 2004; Kenward \& Carrott, 2006). These 
214 included grain weevils (Curculionidae: Sitophilus Schoenherr), carpet beetles (Dermestidae:

215 Anthrenus), grain beetles (Silvanidae: Oryzaephilus Ganglbauer), cigarette and drugstore beetles

216 (Anobiidae: Lasioderma Stephens \& Stegobium Motschulsky, respectively), house flies

217 (Muscidae: Musca domestica) and lesser house flies (Fanniidae: Fannia Robineau-Desvoidy).

218

219

Arthropod Distribution within the Home

220

Arthropods were found on every level of the home and in all room types. Only 5 rooms

221

222

223

224

225

226

227

228

229

230

231

232

233

234

235

236

(non-attics) had no arthropod specimens collected (four bathrooms, one bedroom). Six arthropod orders dominated houses, comprising $81 \%$ of the diversity in an average room: Diptera (true flies, 23\%), Coleoptera (beetles, 19\%), Araneae (spiders, 16\%), Hymenoptera (predominantly ants, 15\%), Psocodea (book lice, 4\%), and Hemiptera (true bugs, 4\%) (Fig. 5). Eight additional orders made up another $15 \%$ of the diversity (Blattodea, Collembola, Lepidoptera, Isopoda, Zygentoma, Polydesmida, Orthoptera, and Acari), while all remaining orders comprised a total of $4 \%$ of the overall diversity (Fig. 5). The percentage of rooms in which an arthropod was collected varied among taxa, as did their presence in rooms of different types (Table 1).

\section{Dust Mite Sampling}

Dust mite samples contained from 0 to 421 total specimens, with an average of 38.12 $($ s.d. $=71.5)$; dust mites were found in $76 \%$ of the homes sampled (Table 1). Significantly more mites were collected from carpeted surfaces than hard surfaces (e.g., wood floors) (KruskalWallis test: $\chi^{2}=10.692, p=0.001$ ). Of those identified from the subset, all were Dermatophagoides sp. (Pyroglyphidae). 


\section{DISCUSSION}

238 As household pests and disease vectors, the indoor arthropods in our daily lives have had

239 a substantial impact on human society both historically and today. Although extensive research

240 has been done on a small number of arthropod pest species, the data presented herein represent

241 the first comprehensive survey of the arthropod diversity collected from urban and suburban

242 houses. In the absence of similar studies that could provide baseline data for comparison, our

243 results are surprising both in terms of the prevalence of arthropods (virtually every room was

244 occupied) and in terms of their diversity.

245 The diversity of arthropods found indoors extends far beyond commonly recognized

246 species. We found that an individual house may have hundreds of arthropod species within it,

247 with each house on average containing 62 families and a minimum estimate of 93

248 morphospecies. The true diversity among these 50 homes is undoubtedly much higher due to

249 limitations of the minimum estimate (it assumes no species turnover between rooms), the

250 presence of cryptic species and our sampling method that excluded areas behind walls, under

251 heavy furniture, and in drawers and cabinets, all of which undoubtedly serve as potential refuges

252 for additional arthropods. While sampling 50 homes did lead to a decrease in the rate of family

253 accumulation, clearly there are still many other families and morphospecies that are yet to be

254 recovered and characterized from homes (Fig. 2).

255 We found that four groups of arthropods dominate the average room: flies (23\%), beetles

256 (19\%), spiders (16\%) and hymenoptera (predominantly ants, 15\%) (Fig. 5). Overall, there are

257 more types of flies associated with human homes than any other group of animals. Some flies

258 have evolved close associations with humans, while others (Chironomidae and Cecidomyiidae)

259 may arrive in houses as part of 'air plankton'; their presence indoors is more a reflection of their 
260 abundance outdoors than of the ecology inside homes. Despite their prevalence, flies represent

261 only a small proportion of taxon-focused studies in the urban landscape (McIntyre, 2000).

262 Recent studies have revealed new information on flies in urban landscapes, including 30 new

263 scuttle fly species identified from urban Los Angeles (California, USA), indicating that the true

264 diversity of these flies, and likely many other small fly groups, in human-developed areas is

265 underestimated (Grimaldi et al., 2015; Hartop et al., 2015).

266 Book lice (Psocodea: Liposcelididae), were found to be amongst the most ubiquitous

267 indoor arthropods (found in 49 of 50 houses). Book lice are close relatives of parasitic lice and

268 have a long evolutionary history of living, amongst other places, in close association with birds,

269 mammals and their nests (including those of primates; Grimaldi \& Engel, 2005). As stored grain

270 pests, fungus feeders, and scavengers, book lice thrive in indoor environments. Liposcelis

271 bostrychophila Badonnel, for example, is a globally-distributed, anthropophilic species whose

272 widespread success and resistance to control measures is in part due to its parthenogenesis,

273 ability to disperse through air, wide diversity of diet, and resistance to starvation (Diaz-Montano

274 et al., 2014). Book lice have become more common in houses in the United Kingdom over time

275 (recovered from 14\% of houses sampled in 1987 versus 30\% in 1997; Turner \& Bishop, 1998)

276 and are more prevalent in areas of high humidity in houses in Spain (such as kitchens and

277 bathrooms; Baz \& Monserrat, 1999). However, perhaps due to North Carolina's humid climate

278 or our sampling methods, we found booklice distributed throughout houses.

279 Dust mites were found in the majority of homes (76\%). Previous studies have found dust 280 mites in 30 to $100 \%$ of sampled homes across the US (Arlian, 1992). Human association with

281 dust mites may have been established with the origins of dense human settlements; dust mites

282 likely shifted from the nests of synanthropic birds or rodents to human houses (Klimov, 2013). 
283 To control dust mite populations, it is often recommended to remove carpets because they

284 provide protection, thermoinsulation, higher humidity, and trap the food on which these mites

285 feed (Colloff, 1998). As expected, we found much higher dust mite abundance on carpeted

286 surfaces, consistent with previous research. Yet, paradoxically, the house that had the single

287 highest abundance of dust mites within our study had a wood floor. Humidity levels and

288 vacuuming frequency, although unknown for this house, may explain the discrepancy.

289 Characteristics of different wood floors, such as age and quality of build, could also affect mite

290 abundance since gaps between boards can provide habitat for mite populations.

291 Because previous studies of indoor arthropods have largely focused on pest groups of

292 economic and human health importance (e.g. Runstrom \& Bennett, 1990; Colloff, 1998; How \&

293 Lee, 2010; Crissman et al., 2010), we expected common pests to be among the most frequently

294 found groups of arthropods in the homes. In fact, we found a relative dearth of typical household

295 pests. The only exception to this was the prevalence of the smoky brown cockroach, a species

296 that is not truly considered pestiferous because it does not generally develop pest-level

297 populations in homes due to its need for high humidity and moisture (Robinson, 2005). It may be

298 that we collected more specimens of this species due to their intolerance and ultimate death

299 within the homes. While the lack of many pest species could be an artifact of the sampling

300 design (sampling for species occurrence rather than abundance, as well as sampling in free-

301 standing homes rather than other forms of human habitation such as apartments, townhouses,

302 etc.), it appears that the vast majority of arthropods that live amongst us cause no direct harm.

303 Unfortunately many insects and arthropods we collected are considered pests based solely on

304 their presence in the home (i.e. nuisance invaders; Hahn \& Ascerno, 1991; Cranshaw, 2011),

305 despite having no direct impact on people or their possessions. 
307 frequency with which they were found or because they are rarely found outdoors, much less 308 indoors. Gall midges (Cecidomyiidae), although found in every house sampled, were not even

309 mentioned amongst the over 2,000 species listed in a recent compilation of urban insects and 310 arachnids (Robinson, 2005). Leafhoppers (Cicadellidae), as plant feeders, are not associated with

311 the indoor biome (Robinson, 2005), yet were among the groups most frequently found in houses.

312 Moths and butterflies (Lepidoptera), on the other hand, were collected infrequently, making up

313 only $2 \%$ of the average diversity in a room; this is disproportionate to their known overall

314 diversity (the order comprising over 10\% of described insect species; Capinera, 2008). Although

315 ants (Formicidae) were expected and found in $100 \%$ of houses, further identification at the genus

316 and species level revealed taxa that are not typically thought to occur in homes. Camel crickets

317 (Rhaphidophoridae) are known basement dwellers in the Southeastern US, but our sampling

318 confirmed previous reports that an invasive species, Diestrammena asynamora (Adelung)

319 predominates over native species (Ceuthophilus spp.) (Epps et al., 2014). Other unexpected finds

320 were ant-loving crickets (Myrmecophilidae), the smallest orthopterans (Whitman, 2008), which

321 were found in five kitchens, all with ant infestations; beetles from the relatively rare suborder

322 Archostemata (families Cupedidae and Micromalthidae); and a larval beaded lacewing

323 (Berothidae), a rarely seen neuropteran known to live within termite nests where they paralyze

324 termites with an airborne chemical before feeding on them (Johnson \& Hagen, 1981).

Of the arthropods we found that live out a portion of their life cycle in human houses, there is a broad diversity of trophic levels and life histories represented. Apart from a few herbivorous arthropods associated with houseplants or those inadvertently living indoors (for

328 example, brought in on cut plants), most taxa sampled from houses were either scavengers, 
329 predators, or parasitoids. Carpet beetles (Dermestidae) were found feeding on dog kibble, dead

330 insects and nail clippings. Other scavengers, like silverfish (found in $68 \%$ of homes) and book

331 lice were also common. Carrion-feeding flesh flies (Sarcophagidae) were found during the study

332 emerging from a rodent killed by a house cat. Spiders (including spitting spiders, Scytodidae,

333 that spit venom up to a centimeter to ensnare prey (Foelix, 1996)) and centipedes (especially

334 Scutigeridae) were the primary predators sampled. Minute parasitoid wasps (especially

335 Eulophidae and Platygastridae s.l.) that potentially parasitize other household arthropods were

336 also common inhabitants. For instance, one species of Eulophidae, Aprostocetus (Tetrastichodes)

337 hagenowii (Supplemental Table 1), a known parasitoid of blattid cockroach egg cases (oothecae),

338 was commonly collected in homes as were its hosts. Considering the range and abundance of life

339 histories found in our study, the trophic dynamics of the indoor ecosystem is an area in need of

340 future study.

341 The rich arthropod diversity we identified from houses reflects a gradient of association

342 with human habitations, from synanthropic arthropods that appear strongly adapted to human

343 houses (cobweb spiders, carpet beetles, book lice), to others that seek shelter and resources only

344 on occasion (ants, ground beetles, hunting spiders, smoky brown cockroaches), to many groups

345 that simply become trapped in houses to their own detriment (leafhoppers, gall midges, click

346 beetles). Most of the arthropod groups we identified do not have life histories that are known to

347 be closely associated with the indoors. Many arthropods may find themselves indoors as a result

348 of the 'Malaise trap effect': houses, like Malaise and other flight intercept traps, are effective at

349 capturing local arthropods that may be travelling through the environment or are attracted to

350 houses by artificial light, food, and shelter. These arthropods may be active in a house for a short

351 period of time, where interactions between them and the house's residents may occur, but 
352 eventually they must either find an exit or succumb to mortality. The idea that homes are traps

353 or filters of local, outdoor arthropod fauna implies the importance of further investigating the

354 dynamics between the greater landscape and the indoor environment.

355 Biodiversity in urban landscapes is richer than was once thought (McKinney, 2008;

356 Fattorini 2011; Fattorini 2014), and we find here that the indoor, manufactured environment also

357 supports more diversity than anticipated. These findings represent a new understanding of the

358 makeup of the indoor arthropod community and their distribution within houses. Arthropods

359 within our homes are both diverse and prevalent, and are a mix of closely synanthropic species

360 and a great diversity of species that wander indoors by accident. Many species we found were

361 unexpected, unnoticed by residents until they were collected, and play no pestiferous role in

362 human houses. Yet, further research on the ecological dynamics of the indoor biome is needed to

363 understand the potential economic and health implications of the species that live and have

364 evolved in such close proximity to us.

365

366

367

368

369

370

371

372

373

374 


\section{ACKNOWLEDGMENTS}

376 We are very much indebted to the many volunteers who allowed us to sample the

377 arthropods in their homes. Kelly Oten aided in designing many aspects of the study and

378 participated in sampling homes. We also thank others who helped collect specimens: Nancy

379 Brill, Mary Jane Epps, Clint Penick, Amy Savage, Patricia Turner, and Steven Turner. Melissa

380 Howell aided in sorting arthropods.

381

382

383

384

385

386

387

388

389

390

391

392

393

394

395

396

397 


\section{REFERENCES}

400 Araújo, A., A. M. Jansen, K. Reinhard, and L. F. Ferreira. 2009. Paleoparasitology of Chagas

401 disease: a review. Memórias do Instituto Oswaldo Cruz 104:9-16.

402

403

404

405

406

407

408

409

410

411

412

413

414

415

416

417

418

419

420

421
Arlian, L. G., D. Bernstein, I. L. Bernstein, S. Friedman, A. Grant, P. Lieberman, M. Lopez, J. Metzger, T. Platts-Mills, M. Schatz, S. Spector, S. I. Wasserman, and R. S. Zeiger. 1992. Prevalence of dust mites in the homes of people with asthma living in eight different geographic areas of the United States. Journal of Allergy and Clinical Immunology. 90:292-300.

Balvín, O., P. Munclinger, L. Kratochvíl, and J. Vilímová. 2012. Mitochondrial DNA and morphology show independent evolutionary histories of bedbug Cimex lectularius (Heteroptera: Cimicidae) on bats and humans. Parasitology Research. 111: 457-469.

Baz, A., and V. J. Monserrat. 1999. Distribution of domestic Psocoptera in Madrid apartments. Medical and Veterinary Entomology 13:259-264.

Belles, X. 1997. Los insectos y el hombre prehistórico. Bol. SEA 20:319-325.

Beal, R. S. 1959. Notes on the biology and systematics of the dermestid beetle genus Aspectus with descriptions of two new species. Annals of the Entomological Society of America, 52:132-137 
422 Booth, W., Santangelo, R. G., Vargo, E. L., Mukha, D. V., \& Schal, C. 2010. Population genetic

423

424

425

426

427

428

429

430

431

432

433

434

435

436

437

438

439

440

441

442

443 structure in German cockroaches (Blattella germanica): differentiated islands in an agricultural landscape. Journal of Heredity 102:175-83

Capinera, J. L. 2008. Butterflies and moths. Encyclopedia of Entomology 4 (2nd ed.). Springer. pp. 626-672. ISBN 9781402062421.

Chopard L. 1928. Sur une gravure d'insecte de l'epoque magdalénienne. Comptes Rendus de la Societé de Biogeographie 5:64-67

Colloff, M. J. 1998. Distribution and abundance of dust mites within homes. Allergy 53:24-27.

Colwell, R. K. 2013. EstimateS: statistical estimation of species richness and shares species from samples. Version 9. User's Guide and application at <http://purl.oclc.org/estimates $>$.

Committee on Urban Pest Management, Environmental Studies Board, Commission on Natural Resources, and National Research Council. 1980. Urban Pest Management. National Academy Press, Washington, D.C.

Cranshaw, W. 2011. A Review of Nuisance Invader Household Pests of the United States. American Entomologist 57:165-169. 
444 Crissman, J. R., Booth, W., Santangelo, R. G., Mukha, D. V., Vargo, E. L., \& Schal, C. (2010).

445

446

447

448

449

450

451

452

453

454

455

456

457

458

459

460

461

462

463

464

465

466
Population genetic structure of the German cockroach (Blattodea: Blattellidae) in apartment buildings. Journal of medical entomology, 47(4), 553-564.

Dunn, R. R., N. Fierer, J. B. Henley, J. W. Leff, and H. L. Menninger. 2013. Home Life: Factors Structuring the Bacterial Diversity Found within and between Homes. PLoS One 8:e64133.

Diaz-Montano, J., J. F. Campbell, T. W. Phillips, and J. E. Throne. 2014. Evaluation of Potential Attractants for Liposcelis bostrychophila (Psocoptera: Liposcelididae). Journal of Economic Entomology 107:867-874. doi: http://dx.doi.org/10.1603/EC13427

Disney, R. H. L. (2008). Natural history of the scuttle fly, Megaselia scalaris. Annu. Rev. Entomol. 53:39-60.

Epps, M. J., Menninger, H. L., LaSala, N., \& Dunn, R. R. 2014. Too big to be noticed: cryptic invasion of Asian camel crickets in North American houses. PeerJ, 2, e523.

Fattorini S. 2014. Urban biodiversity hotspots are not related to the structure of green spaces: a case study of tenebrionid beetles from Rome, Italy. Urban Ecosystems, 17:1033-1045

Fattorini S. 2011. Insect extinction by urbanization: a long term study in Rome. Biological Conservation, 144: 370-375. 
468 Foelix, R. 2010. Biology of spiders. Oxford University Press.

469

470 Grimaldi, D., P. S. Ginsberg, L. Thayer, S. McEvey, M. Hauser, M. Turelli, and B. Brown. 2015. Strange Little Flies in the Big City: Exotic Flower-Breeding Drosophilidae (Diptera) in Urban Los Angeles. PLOS ONE. e0122575 DOI: 10.1371/journal.pone.0122575

473

474

Grimaldi, D., and M. Engel 2005. Evolution of the Insects. Oxford University Press. 755 pages.

475

476

477

Hahn, J. D. and M. E. Ascerno. 1991. Public attitudes toward urban arthropods in Minnesota. American Entomologist 37:179-185.

478

Hartop, E. A., B.V. Brown, and R.H. Disney. 2015. Opportunity in our Ignorance: Urban Biodiversity Study Reveals 30 New Species and One New Nearctic Record for Megaselia (Diptera: Phoridae) in Los Angeles (California, USA). Zootaxa 3941: 451-484.

How, Y. F., \& Lee, C. Y. 2010. Survey of bed bugs in infested premises in Malaysia and Singapore. Journal of Vector Ecology, 35(1), 89-94.

484

485

486

Johnson, R. A. 2000. Seed-harvester ants (Hymenoptera: Formicidae) of North America: an . overview of ecology and biogeography. Sociobiology 36:89-122.

487

Johnson, J. B., \& Hagen, K. S. 1981. A neuropterous larva uses an allomone to attack termites. Nature. 289:506 - 507 
491 Kenward, H., and J. Carrott. 2006. Insect species associations characterise past occupation sites. Journal of Archaeological Science 33:1452-1473.

493

494

495

496

497

498

499

500

501

502

503

504

505

506

507

508

509

510

511

Keller, A. 2007. Drosophila melanogaster's history as a human commensal. Current Biology, 17(3), R77-R81.

Kislev, M. E., A. Hartmann, and E. Galili. 2004. Archaeobotanical and archaeoentomological evidence from a well at Atlit-Yam indicates colder, more humid climate on the Israeli coast during the PPNC period. Journal of Archaeological Science 31:1301-1310.

Klimov, P. B., and B. O’Connor. 2013. Is permanent parasitism reversible?-Critical evidence from early evolution of house dust mites. Systematic biology: syt008. DOI: 10.1093/sysbio/syt008

Krantz, G. W., \& Walter, D. E. 2009. A manual of acarology, $3^{\text {rd }}$ Ed. Texas Tech University Press

NESCent Working Group on the Evolutionary Biology of the Built Environment, L. J. Martin, R. I. Adams, A. Bateman, H. M. Bik, J. Hawks, S. M. Hird, D. Hughes, S. W. Kembel, K. Kinney, S-O. Kolokotronis, G. Levy, C. McClain, J. F. Meadow, R. F. Medina, G. Mhuireach, C. S. Moreau, J. Munshi-South, L. M. Nichols, C. Palmer, L. Popova, C. 
512

513

514

515

516

517

518

519

520

521

522

523

524

525

526

527

528

529

530

531

532

533

534

Schal, M. Täubel, M. Trautwein, J. A. Ugalde, and R. R. Dunn. 2015. Evolution of the indoor biome. Trends in Ecology \& Evolution 30:223-232

Legner, E. F., \& McCoy, C. W. 1966. The housefly, Musca domestica Linnaeus, as an exotic species in the Western Hemisphere incites biological control studies. The Canadian Entomologist, 98(03), 243-248.

McIntyre, N. E. 2000. Ecology of urban arthropods: a review and a call to action. Annals of the Entomological Society of America, 93:825-835.

McKinney, M. L. 2008. Effects of urbanization on species richness: A review of plants and animals. Urban Ecosystems 11:161-176.

Moore, C. G. 1999. Aedes albopictus in the United States: current status and prospects for further spread. Journal of the American Mosquito Control Association, 15:221-227.

Nielsen, B. O., V. Mahler, and P. Rasmussen. 2000. An arthropod assemblage and the ecological conditions in a byre at the Neolithic settlement of Weier, Switzerland. Journal of Archaeological Science 27:209-218.

Oliver, I. \& A.J. Beattie. 2002. Invertebrate morphospecies as surrogates for species: a case study. Conservation Biology 10: 99-109. 
535 Panagiotakopulu, E. 2001. New records for ancient pests: archaeoentomology in Egypt. Journal 536 of Archaeological Science 28:1235-1246.

537

538 Panagiotakopulu, E. 2003 Insect remains from the collections in the Egyptian Museum of Turin. Archaeometry 45:355-362.

540

541 Pates, H., \& Curtis, C. (2005). Mosquito behavior and vector control. Annu. Rev. Entomol., 542 50:53-70.

543

544 Panagiotakopulu, E. 2004. Dipterous remains and archaeological interpretation. Journal of 545 Archaeological Science 31:1675-1684.

546

547

548

Robinson, W. H. 2005. Urban insects and arachnids: a handbook of urban entomology. Cambridge University Press, Cambridge.

Roth LM. 1985. A taxonomic revision of the genus Blattella Caudell (Dictyoptera, Blattaria, Blattellidae). Entomol Scand. 22:1-221.

552

553 Runstrom, E. S., \& Bennett, G. W. 1990. Distribution and movement patterns of German 554 555 cockroaches (Dictyoptera: Blattellidae) within apartment buildings. J. Med. Entomol, $27(4), 515-518$ 
556 Turner, B.D. \& H. Maude-Roxby. 1989. The prevalence of the booklouse Liposcelis

557

558

559

560

561

562

563

564

565

566

567

568

569

570

571

572

573

574

575

576

577

578 bostrychophilus Badonnel (Liposcelidae, Psocoptera) in British domestic kitchens. International Pest Control 31:93-97.

Turner, B. D. \& Bishop, J. 1998 An analysis of the incidence of psocids in domestic kitchens: the PPFA 1997 household survey (What's bugging your kitchen). Environmental Health Journal 106, 310-314.

3

4 Whitman, D. W. 2008. The significance of body size in the Orthoptera: a review. Journal of Orthoptera Research, 17:117-134.

66

(1)

(1)

.


579 Figure 1. Map of study sites. Fifty homes (denoted by stars) were selected in and around the

580 Raleigh, North Carolina area. Raleigh is within Wake County, highlighted in red on the state

581 map below, though some samples fell within adjacent counties.

582

583

584

Figure 2. Family accumulation curve. The mean, along with 95\% lower and upper confidence intervals, was calculated based on the complete list of families acquired over each sampled house using the Chao2 Estimator with 1000 randomization runs in EstimateS (Colwell, 2013).

Figure 3. Number of species by house (in ascending rank order of house size). The number of species collected by house is represented by the middle bar. The bottom limit is the conservative estimated morphospecies by house which was calculated by summing the maximum number of morphospecies for every arthropod family between all rooms within each house. The upper limit is the maximum possible of morphospecies within a house, with the assumption that each set of morphospecies within each room were unique from other rooms. Houses furthest to the left are the smallest in terms of square footage, and those furthest to the right are the largest. Houses ranged in size from 840-4833 square feet.

Figure 4. Photographic representatives of the most frequently collected arthropod families. Twelve (12) families were represented in at least $80 \%$ of homes. For each family we present the common name and percentage of homes it was found in, followed in parentheses by the scientific family name and species level identification when possible. A) cobweb spiders, $100 \%$

600 (Theridiidae; shown here Parasteatoda tepidariorum (Koch)); B) carpet beetles, 100\%, 601 (Dermestidae; shown here Anthrenus larvae); C) gall midges, 100\% (Cecidomyiidae); D) ants, 
$602100 \%$ (Formicidae; shown here Monomorium minimum (Buckley)); E) book lice, 98\%

603 (Liposcelididae); F) dark-winged fungus gnats, 96\% (Sciaridae); G) cellar spiders, 84\%

604 (Pholcidae; shown here Pholcus sp.); H) weevils, 82\% (Curculionidae; shown here Sitophilus 605 zeamais (Motschulsky)); I) mosquitoes, 82\% (Culicidae; shown here Aedes albopictus (Skuse));

606 J) scuttle flies, 82\% (Phoridae; shown here Dohrniphora incisuralis (Loew)); K) leafhoppers, $60782 \%$ (Cicadellidae; shown here Sibovia sp.); L) non-biting midges, 80\% (Chironomidae). All 608 photos by MAB.

609

610 Figure 5. Proportional diversity of arthropod orders across all rooms. Average

611 morphospecies composition calculated across all room types. All photos by MAB.

612

613 Table 1. List of arthropods found during the study present in at least $10 \%(n=5)$ of homes.

614 Table includes the percentage of homes, rooms overall, and six specific room types (attics, 615 basements, bathrooms, bedrooms, common areas, and kitchens) where a taxon was collected.

616 One hundred twenty-eight additional families were collected, but were found in less than $10 \%$ $617(\mathrm{n}=5)$ of homes. For the full table containing all taxa (including genera and species that were 618 identified) see Supplemental Table 1. All names are based on current taxonomy except for mites, 619 where "Acari" is used as a general order despite modern classifications that consider the group a 620 subclass with numerous orders (Krantz \& Walter, 2009). s.l. = sensu lato, i.e. "broad sense" 
1

Map of study sites.

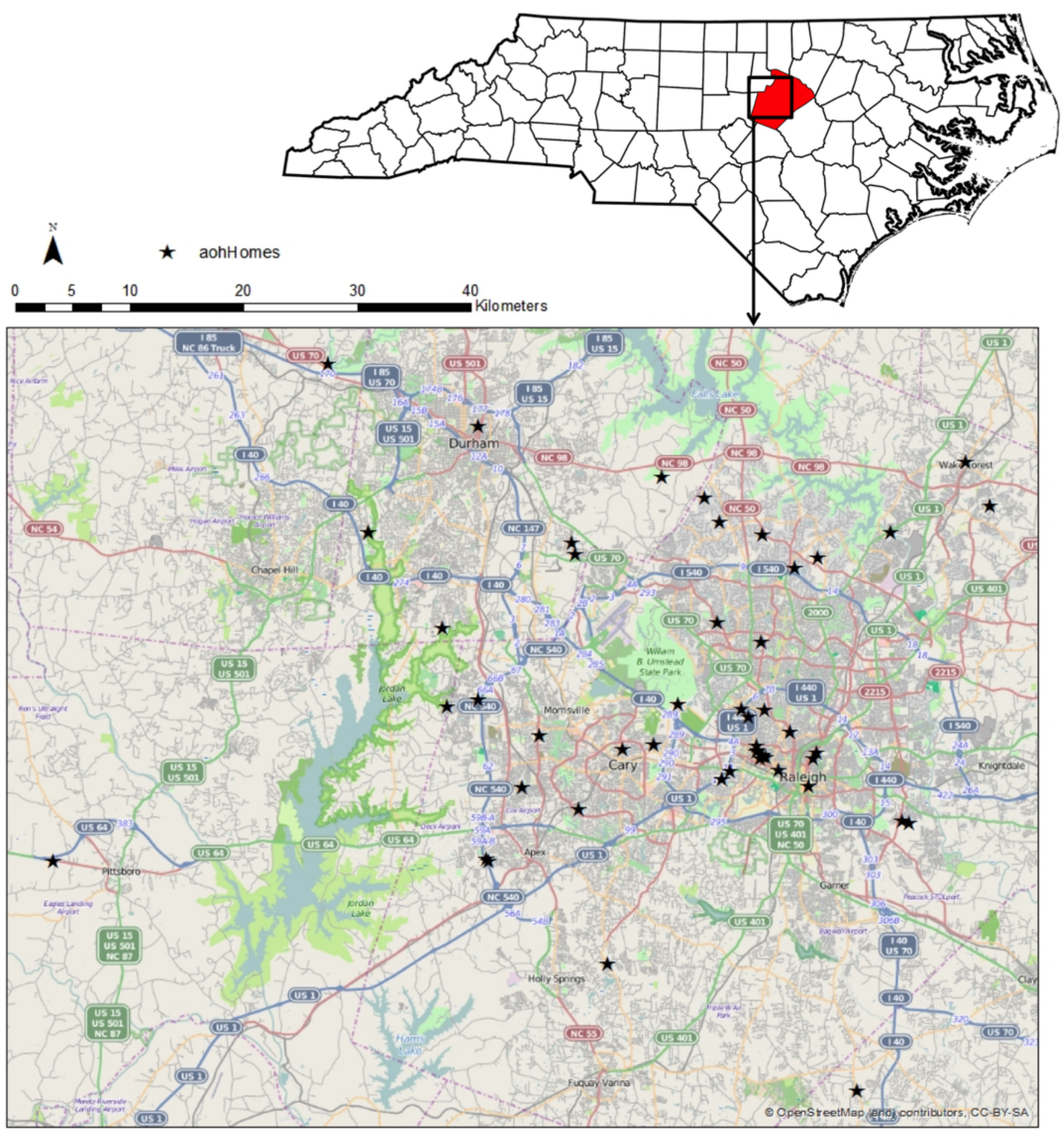


2

Family accumulation curve.

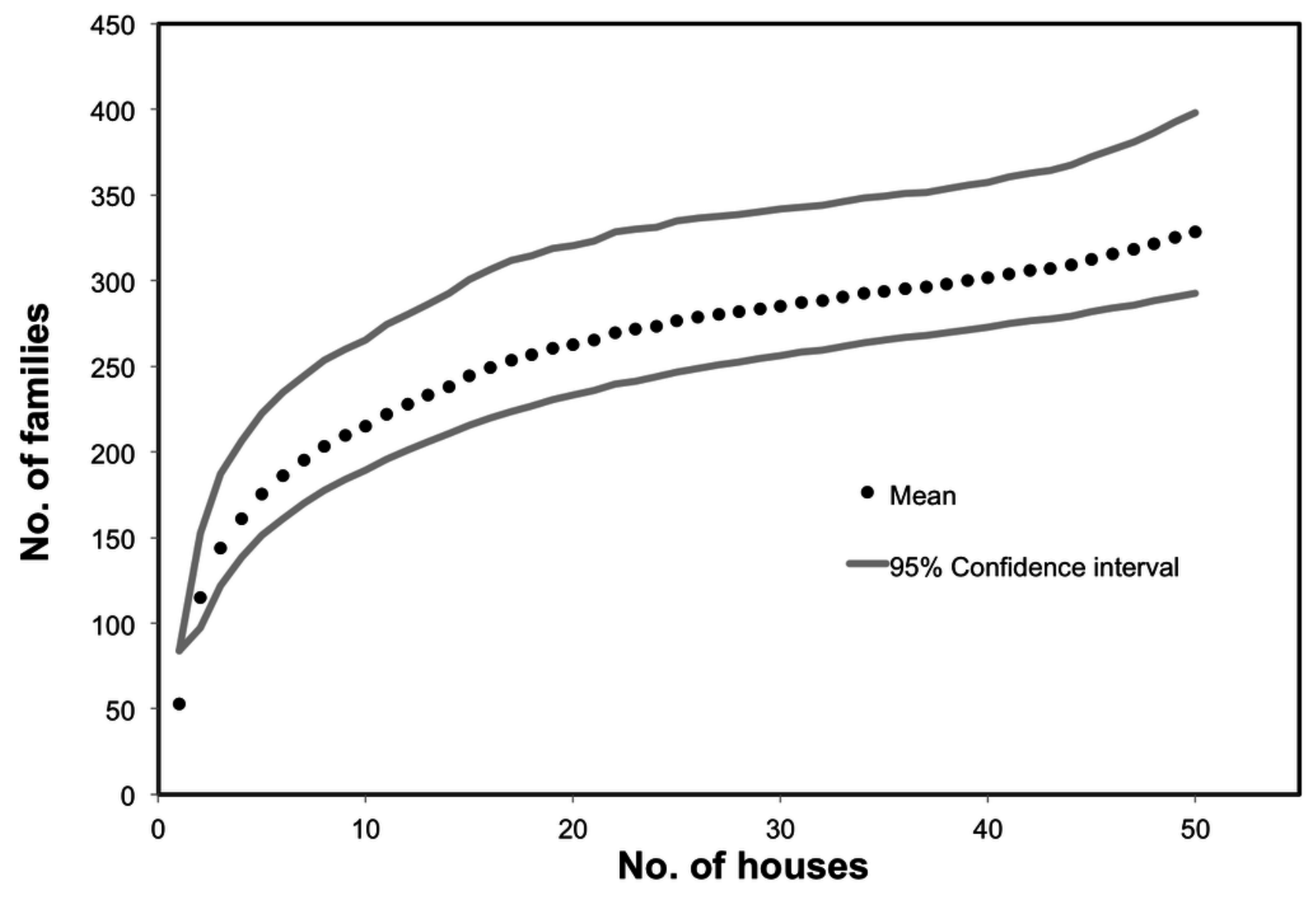


3

Number of species by house (in ascending rank order of house size).

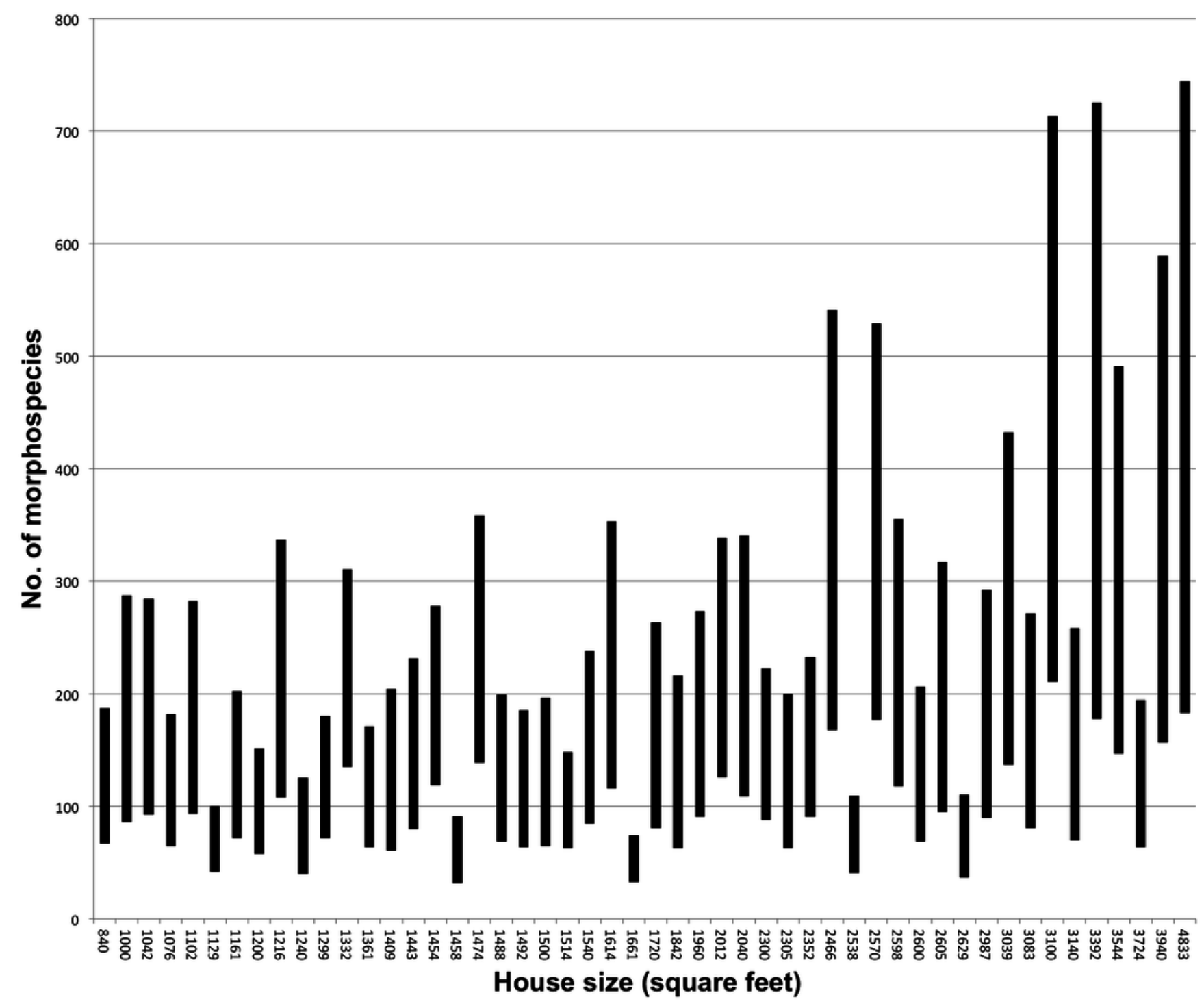


4

Photographic representatives of the most frequently collected arthropod families. 

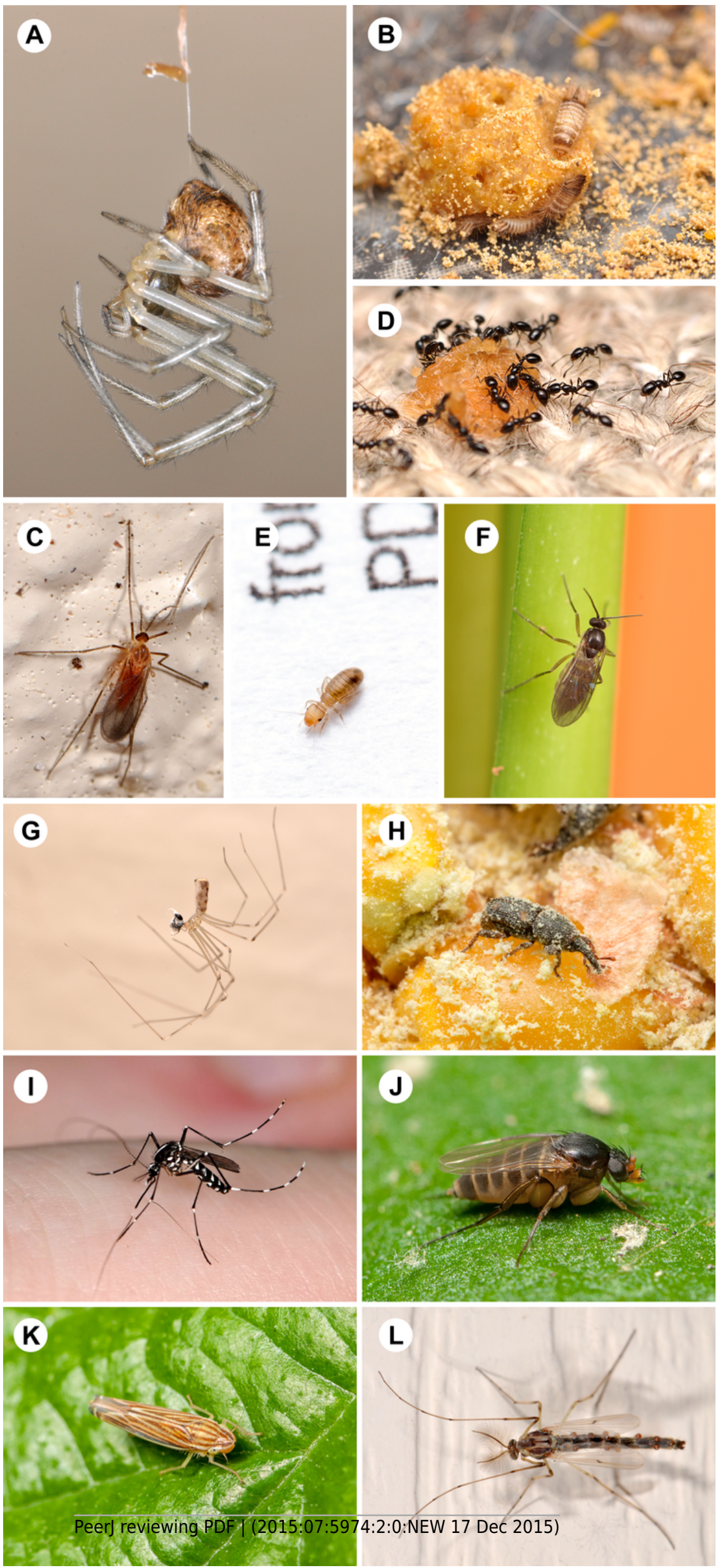


\section{5}

Proportional diversity of arthropod orders across all rooms.

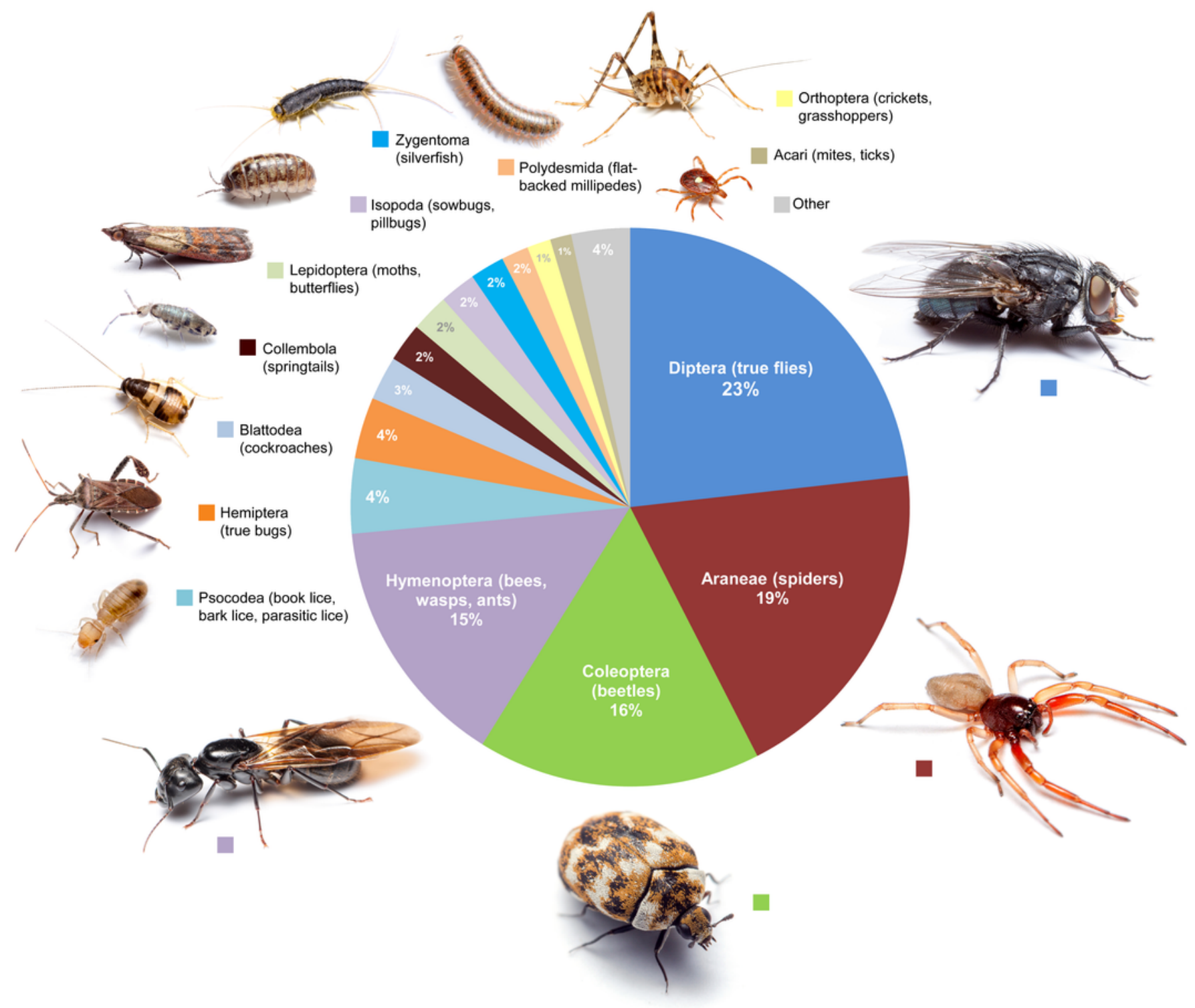




\section{Table $\mathbf{1}$ (on next page)}

List of arthropods found during the study present in at least $10 \%(n=5)$ of homes. 


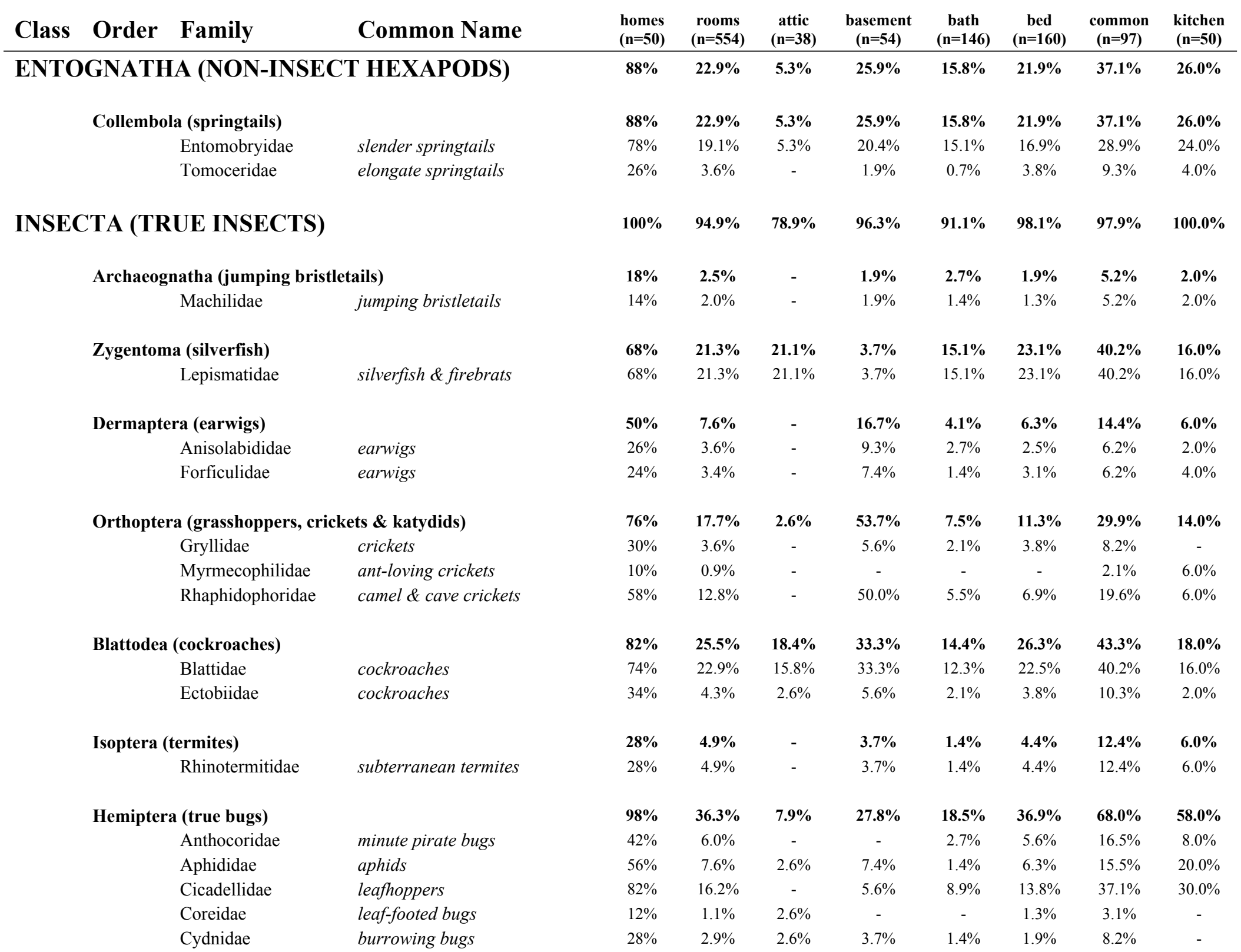




$\begin{array}{ll}\text { Delphacidae } & \text { delphacid planthoppers } \\ \text { Lygaeidae } & \text { seed bugs } \\ \text { Miridae } & \text { plant bugs } \\ \text { Pentatomidae } & \text { stink bugs } \\ \text { Psyllidae s.l. } & \text { jumping } \text { plant lice } \\ \text { Reduviidae } & \text { assassin bugs } \\ \text { Rhyparochromidae } & \text { dirt-colored seed bugs } \\ \text { Tingidae } & \text { lace bugs }\end{array}$

Psocodea (lice)

$\begin{array}{ll}\text { Ectopsocidae } & \text { bark lice } \\ \text { Lepidopsocidae } & \text { scaly-winged bark lice } \\ \text { Liposcelididae } & \text { booklice }\end{array}$

\section{Thysanoptera (thrips)}

$\begin{array}{ll}\text { Phlaeothripidae } & \text { tube-tailed thrips } \\ \text { Thripidae } & \text { common thrips }\end{array}$

Hymenoptera (wasps, ants \& bees)

$\begin{array}{ll}\text { Bethylidae } & \text { bethylid wasps } \\ \text { Braconidae } & \text { braconid wasps } \\ \text { Ceraphronidae } & \text { ceraphronid wasps } \\ \text { Chalcididae } & \text { chalcidid wasps } \\ \text { Diapriidae } & \text { diapriid wasps } \\ \text { Encyrtidae } & \text { encyrtid wasps } \\ \text { Eulophidae } & \text { eulophid wasps } \\ \text { Formicidae } & \text { ants } \\ \text { Halictidae } & \text { sweat bees } \\ \text { Ichneumonidae } & \text { ichneumon wasps } \\ \text { Mymaridae } & \text { fairyflies } \\ \text { Platygastridae s.l. } & \text { platygastrid wasps } \\ \text { Pompilidae } & \text { spider wasps } \\ \text { Pteromalidae } & \text { pteromalid wasps } \\ \text { Sphecidae s.l. } & \text { thread-waisted wasps } \\ \text { Vespidae } & \text { paper wasps \& hornets }\end{array}$

Neuroptera (lacewings, antlions, etc)

Chrysopidae

green lacewings

\begin{tabular}{|c|c|c|c|c|c|c|c|}
\hline $12 \%$ & $1.4 \%$ & - & $1.9 \%$ & $1.4 \%$ & $0.6 \%$ & $3.1 \%$ & - \\
\hline $10 \%$ & $1.4 \%$ & - & - & $0.7 \%$ & $1.3 \%$ & $4.1 \%$ & - \\
\hline $44 \%$ & $6.5 \%$ & - & - & $2.1 \%$ & $5.6 \%$ & $19.6 \%$ & $8.0 \%$ \\
\hline $22 \%$ & $2.5 \%$ & $5.3 \%$ & - & - & $3.1 \%$ & $5.2 \%$ & $4.0 \%$ \\
\hline $10 \%$ & $0.9 \%$ & - & - & $0.7 \%$ & - & $3.1 \%$ & $2.0 \%$ \\
\hline $28 \%$ & $3.4 \%$ & - & $3.7 \%$ & - & $1.9 \%$ & $11.3 \%$ & $4.0 \%$ \\
\hline $30 \%$ & $3.8 \%$ & - & $3.7 \%$ & $4.1 \%$ & $1.9 \%$ & $9.3 \%$ & $2.0 \%$ \\
\hline $16 \%$ & $1.6 \%$ & - & $1.9 \%$ & $1.4 \%$ & $1.3 \%$ & $4.1 \%$ & - \\
\hline $98 \%$ & $43.1 \%$ & $36.8 \%$ & $24.1 \%$ & $31.5 \%$ & $50.6 \%$ & $60.8 \%$ & $46.0 \%$ \\
\hline $16 \%$ & $2.0 \%$ & - & - & - & $2.5 \%$ & $5.2 \%$ & $4.0 \%$ \\
\hline $24 \%$ & $4.3 \%$ & $2.6 \%$ & - & $0.7 \%$ & $5.6 \%$ & $13.4 \%$ & - \\
\hline $98 \%$ & $37.4 \%$ & $34.2 \%$ & $16.7 \%$ & $28.1 \%$ & $44.4 \%$ & $52.6 \%$ & $38.0 \%$ \\
\hline $50 \%$ & $7.0 \%$ & $2.6 \%$ & $5.6 \%$ & $2.7 \%$ & $4.4 \%$ & $19.6 \%$ & $8.0 \%$ \\
\hline $14 \%$ & $1.4 \%$ & - & $1.9 \%$ & $0.7 \%$ & $0.6 \%$ & $5.2 \%$ & - \\
\hline $32 \%$ & $4.2 \%$ & $2.6 \%$ & - & $2.1 \%$ & $2.5 \%$ & $11.3 \%$ & $6.0 \%$ \\
\hline $100 \%$ & $69.7 \%$ & $50.0 \%$ & $64.8 \%$ & $50.7 \%$ & $78.8 \%$ & $85.6 \%$ & $84.0 \%$ \\
\hline $28 \%$ & $3.8 \%$ & - & $1.9 \%$ & $0.7 \%$ & $2.5 \%$ & $14.4 \%$ & $2.0 \%$ \\
\hline $52 \%$ & $7.6 \%$ & - & - & $4.1 \%$ & $8.8 \%$ & $19.6 \%$ & $6.0 \%$ \\
\hline $14 \%$ & $1.4 \%$ & - & $1.9 \%$ & - & - & $7.2 \%$ & - \\
\hline $14 \%$ & $1.4 \%$ & - & - & $0.7 \%$ & $1.9 \%$ & $4.1 \%$ & - \\
\hline $26 \%$ & $2.5 \%$ & - & $5.6 \%$ & - & $1.3 \%$ & $8.2 \%$ & $2.0 \%$ \\
\hline $12 \%$ & $1.4 \%$ & - & - & - & $1.9 \%$ & $4.1 \%$ & - \\
\hline $70 \%$ & $17.0 \%$ & - & $7.4 \%$ & $13.0 \%$ & $16.9 \%$ & $30.9 \%$ & $22.0 \%$ \\
\hline $100 \%$ & $61.9 \%$ & $47.4 \%$ & $57.4 \%$ & $41.8 \%$ & $66.3 \%$ & $81.4 \%$ & $82.0 \%$ \\
\hline $10 \%$ & $0.9 \%$ & $2.6 \%$ & $1.9 \%$ & $0.7 \%$ & - & - & $4.0 \%$ \\
\hline $38 \%$ & $4.5 \%$ & $2.6 \%$ & $5.6 \%$ & $1.4 \%$ & $4.4 \%$ & $9.3 \%$ & $4.0 \%$ \\
\hline $26 \%$ & $2.3 \%$ & - & - & $0.7 \%$ & - & $11.3 \%$ & $2.0 \%$ \\
\hline $58 \%$ & $8.3 \%$ & - & - & $6.2 \%$ & $5.6 \%$ & $27.8 \%$ & $2.0 \%$ \\
\hline $34 \%$ & $6.5 \%$ & $2.6 \%$ & $7.4 \%$ & $2.7 \%$ & $5.6 \%$ & $17.5 \%$ & - \\
\hline $42 \%$ & $4.9 \%$ & - & - & $2.1 \%$ & $3.8 \%$ & $10.3 \%$ & $16.0 \%$ \\
\hline $26 \%$ & $3.2 \%$ & $2.6 \%$ & $1.9 \%$ & $2.7 \%$ & $3.8 \%$ & $6.2 \%$ & - \\
\hline $14 \%$ & $1.6 \%$ & $5.3 \%$ & $1.9 \%$ & - & $1.9 \%$ & $3.1 \%$ & - \\
\hline $56 \%$ & $6.9 \%$ & - & $3.7 \%$ & $2.7 \%$ & $4.4 \%$ & $20.6 \%$ & $10.0 \%$ \\
\hline $34 \%$ & $3.6 \%$ & - & $1.9 \%$ & $1.4 \%$ & $2.5 \%$ & $11.3 \%$ & $4.0 \%$ \\
\hline
\end{tabular}


Coniopterygidae

Hemerobiidae

\section{Coleoptera (beetles)}

Aderidae

Anobiidae

Anthicidae

Carabidae

Cerambycidae

Chrysomelidae

Cleridae

Coccinellidae

Cryptophagidae

Curculionidae

Dermestidae

Elateridae

Histeridae

Lampyridae

Latridiidae

Melyridae

Mordellidae

Mycetophagidae

Nitidulidae

Phalacridae

Ptilodactylidae

Scarabaeidae

Scraptiidae

Silvanidae

Staphylinidae

Tenebrionidae

Throscidae

Trogossitidae

Zopheridae dustywings

brown lacewings

ant-like leaf beetles

death watch beetles

ant-like flower beetles

ground beetles

longhorned beetles

leaf beetles

checkered beetles

ladybugs

silken fungus beetles

weevils, bark beetles

carpet beetles

click beetles

clown beetles

fireflies

minute brown scavenger beetles

soft-winged flower beetles

tumbling flower beetles

hairy fungus beetles

sap beetles

shining flower beetles

ptilodactylid beetles

scarab beetles

false flower beetles

flat bark beetles

rove beetles

darkling beetles

false metallic wood boring beetles

bark gnawing beetles

ironclad beetles

$\begin{array}{rccccccc}16 \% & 1.4 \% & - & - & 0.7 \% & 1.3 \% & 4.1 \% & 2.0 \% \\ 18 \% & 1.8 \% & - & - & - & - & 7.2 \% & 6.0 \% \\ & & & & & & & \\ \mathbf{1 0 0 \%} & \mathbf{7 2 . 0 \%} & \mathbf{4 4 . 7 \%} & \mathbf{6 4 . 8 \%} & \mathbf{5 4 . 1 \%} & \mathbf{8 4 . 4 \%} & \mathbf{9 1 . 8 \%} & \mathbf{7 2 . 0 \%} \\ 22 \% & 2.5 \% & - & - & 0.7 \% & 3.1 \% & 5.2 \% & 6.0 \% \\ 60 \% & 12.1 \% & - & 7.4 \% & 5.5 \% & 10.6 \% & 30.9 \% & 14.0 \% \\ 18 \% & 2.3 \% & 2.6 \% & - & 0.7 \% & 1.9 \% & 7.2 \% & - \\ 66 \% & 9.9 \% & 7.9 \% & 33.3 \% & 4.1 \% & 6.9 \% & 14.4 \% & 2.0 \% \\ 16 \% & 1.6 \% & - & - & 0.7 \% & 3.1 \% & 3.1 \% & - \\ 46 \% & 6.0 \% & - & - & 1.4 \% & 8.1 \% & 17.5 \% & 2.0 \% \\ 18 \% & 1.8 \% & - & - & 1.4 \% & 3.1 \% & 3.1 \% & - \\ 52 \% & 7.8 \% & 5.3 \% & 1.9 \% & 0.7 \% & 8.8 \% & 22.7 \% & 4.0 \% \\ 26 \% & 3.2 \% & - & - & - & 2.5 \% & 12.4 \% & 4.0 \% \\ 82 \% & 15.7 \% & 2.6 \% & 18.5 \% & 9.6 \% & 16.3 \% & 34.0 \% & 6.0 \% \\ 100 \% & 57.0 \% & 26.3 \% & 22.2 \% & 44.5 \% & 71.3 \% & 82.5 \% & 58.0 \% \\ 74 \% & 14.6 \% & 5.3 \% & 13.0 \% & 5.5 \% & 12.5 \% & 39.2 \% & 8.0 \% \\ 10 \% & 0.9 \% & - & 1.9 \% & 0.7 \% & 0.6 \% & 2.1 \% & - \\ 20 \% & 2.2 \% & 2.6 \% & 1.9 \% & - & 1.3 \% & 6.2 \% & 4.0 \% \\ 38 \% & 6.3 \% & - & 1.9 \% & 1.4 \% & 5.6 \% & 16.5 \% & 12.0 \% \\ 20 \% & 2.9 \% & - & 1.9 \% & 2.7 \% & 3.1 \% & 5.2 \% & 2.0 \% \\ 24 \% & 3.6 \% & 2.6 \% & 3.7 \% & 0.7 \% & 3.1 \% & 8.2 \% & 4.0 \% \\ 20 \% & 1.8 \% & 2.6 \% & - & - & 2.5 \% & 4.1 \% & 2.0 \% \\ 24 \% & 3.1 \% & - & 3.7 \% & - & 2.5 \% & 10.3 \% & 2.0 \% \\ 12 \% & 1.3 \% & - & 1.9 \% & - & 0.6 \% & 5.2 \% & - \\ 30 \% & 4.9 \% & 2.6 \% & 3.7 \% & 2.1 \% & 5.6 \% & 9.3 \% & 6.0 \% \\ 52 \% & 9.4 \% & 5.3 \% & 13.0 \% & 2.7 \% & 8.1 \% & 20.6 \% & 10.0 \% \\ 20 \% & 2.0 \% & - & - & 0.7 \% & 1.9 \% & 6.2 \% & 2.0 \% \\ 46 \% & 6.5 \% & - & 9.3 \% & 2.1 \% & 5.0 \% & 17.5 \% & 4.0 \% \\ 54 \% & 7.2 \% & - & 7.4 \% & 4.8 \% & 5.0 \% & 17.5 \% & 6.0 \% \\ 62 \% & 11.2 \% & 5.3 \% & 16.7 \% & 4.8 \% & 11.3 \% & 24.7 \% & 2.0 \% \\ 22 \% & 2.7 \% & - & 1.9 \% & 0.7 \% & 1.9 \% & 9.3 \% & 2.0 \% \\ 16 \% & 1.4 \% & - & - & 0.7 \% & 0.6 \% & 6.2 \% & - \\ 16 \% & 1.4 \% & - & - & - & 2.5 \% & 1.0 \% & 6.0 \% \\ & & & & & & & \\ \mathbf{9 2 \%} & \mathbf{2 8 . 7 \%} & - & \mathbf{1 6 . 7 \%} & \mathbf{1 1 . 6 \%} & \mathbf{3 3 . 8 \%} & \mathbf{5 6 . 7 \%} & \mathbf{3 8 . 0 \%} \\ 12 \% & 1.6 \% & - & 1.9 \% & 0.7 \% & 1.9 \% & 2.1 \% & 2.0 \% \\ 44 \% & 5.8 \% & - & 3.7 \% & 4.1 \% & 5.0 \% & 12.4 \% & 6.0 \% \\ 62 \% & 11.0 \% & - & 3.7 \% & 4.8 \% & 12.5 \% & 21.6 \% & 22.0 \% \\ 60 \% & 8.8 \% & - & - & 5.5 \% & 9.4 \% & 19.6 \% & 10.0 \% \\ & & & & & & & \end{array}$


Tortricidae

Trichoptera (caddisflies)

Siphonaptera (fleas)

Pulicidae

Diptera (true flies)

$\begin{array}{ll}\text { Agromyzidae } & \text { leafminer flies } \\ \text { Anisopodidae } & \text { wood gnats } \\ \text { Anthomyiidae } & \text { root maggot flies } \\ \text { Bibionidae } & \text { march flies, lovebugs } \\ \text { Calliphoridae } & \text { blow flies } \\ \text { Cecidomyiidae } & \text { gall midges } \\ \text { Ceratopogonidae } & \text { biting midges } \\ \text { Chaoboridae } & \text { phantom midges } \\ \text { Chironomidae } & \text { non-biting midges } \\ \text { Chloropidae } & \text { frit flies } \\ \text { Culicidae } & \text { mosquitoes } \\ \text { Dolichopodidae } & \text { longlegged flies } \\ \text { Drosophilidae } & \text { fruit flies, vinegar flies } \\ \text { Empididae s.l. } & \text { dance flies } \\ \text { Ephydridae } & \text { shore flies } \\ \text { Fanniidae } & \text { lesser house flies } \\ \text { Lauxaniidae } & \text { lauxaniid flies } \\ \text { Milichiidae } & \text { freeloader flies } \\ \text { Muscidae } & \text { house \& stable flies } \\ \text { Mycetophilidae s.l. } & \text { fungus gnats } \\ \text { Phoridae } & \text { scuttle flies } \\ \text { Psychodidae } & \text { moth flies } \\ \text { Sarcophagidae } & \text { flesh flies } \\ \text { Scatopsidae } & \text { minute black scavenger flies } \\ \text { Sciaridae } & \text { dark-winged fungus gnats } \\ \text { Sphaeroceridae } & \text { lesser dung flies } \\ \text { Stratiomyidae } & \text { soldier flies } \\ \text { Tachinidae } & \text { tachinid flies } \\ \text { Tipulidae s.l. } & \text { crane flies } \\ \text { Trichoceridae } & \text { winter crane flies } \\ & \\ & \end{array}$

leafroller moths

cat, dog \& human fleas

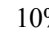

$12 \%$

$10 \%$

$10 \%$

$\mathbf{1 0 0} \%$
$12 \%$

$10 \%$

$10 \%$

$26 \%$

$48 \%$

$100 \%$

$54 \%$

$14 \%$

$80 \%$

$28 \%$

$82 \%$

$44 \%$

$66 \%$

$16 \%$

$14 \%$

$10 \%$
$16 \%$

$16 \%$

$14 \%$

$44 \%$

$68 \%$

$82 \%$

$74 \%$

$38 \%$

$50 \%$

$96 \%$

$28 \%$

$22 \%$

$18 \%$

$74 \%$
$20 \%$
$1.1 \%$

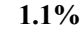

$1.4 \%$

$1.4 \%$

$\mathbf{7 1 . 8 \%}$

$1.1 \%$

$0.9 \%$

$0.9 \%$$$
8.1 \%
$$

$7.6 \%$

$3.4 \%$

$17.0 \%$

$4.3 \%$

$19.0 \%$

$4.9 \%$

$13.7 \%$

$1.8 \%$

$1.4 \%$

$1.1 \%$$$
1.6 \%
$$

$$
6.3 \%
$$

$6.3 \%$
$16.2 \%$

$16.2 \%$
$17.3 \%$

$18.8 \%$$$
5.1 \%
$$

$6.9 \%$

$42.1 \%$

$$
3.4 \%
$$

$$
2.3 \%
$$

$1.6 \%$

$1.6 \%$
$15.9 \%$
$2.3 \%$

\section{$18.4 \%$}

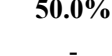

$-$

-

-

-

$\begin{array}{cc}- & 5.6 \% \\ 0.5 \% & 16.7 \%\end{array}$

-

$3.7 \%$

-

$5.6 \%$

$3.7 \%$

$5.6 \%$

$1.9 \%$

-

$1.9 \%$

-

-

$5.6 \%$

$9.3 \%$

$20.4 \%$

$9.3 \%$

-

$1.9 \%$

$22.2 \%$

$11.1 \%$

$1.9 \%$

$-$

$7.4 \%$

$1.9 \%$
$0.7 \%$

$\mathbf{0 . 7 \%}$

$1.3 \%$

$3.1 \%$

$2.7 \% \quad 1.3 \% \quad 1.0 \%$

$2.7 \%$

$1.3 \%$

$1.0 \%$
$1.0 \%$

$2.0 \%$

$\begin{array}{llll}\mathbf{6 6 . 4} \% & \mathbf{8 5 . 6 \%} & \mathbf{8 5 . 6 \%} & \mathbf{8 0 . 0} \%\end{array}$

$\begin{array}{llll}0.7 \% & 0.6 \% & 3.1 \% & 2.0 \%\end{array}$

$\begin{array}{llll}- & 0.6 \% & 3.1 \% & 2.0 \%\end{array}$

$\begin{array}{llll}- & 1.3 \% & 1.0 \% & 4.0 \%\end{array}$

$\begin{array}{llll}0.7 \% & 3.8 \% & 7.2 \% & 2.0 \%\end{array}$

$\begin{array}{llll}2.7 \% & 7.5 \% & 23.7 \% & 6.0 \%\end{array}$

$30.1 \% \quad 33.8 \% \quad 63.9 \% \quad 46.0 \%$

$\begin{array}{llll}3.4 \% & 8.8 \% & 18.6 \% & 10.0 \%\end{array}$

$\begin{array}{llll}3.4 \% & 1.9 \% & 8.2 \% & 6.0 \%\end{array}$

$8.9 \% \quad 13.8 \% \quad 42.3 \% \quad 30.0 \%$

$\begin{array}{llll}3.4 \% & 3.1 \% & 10.3 \% & 8.0 \%\end{array}$

$\begin{array}{llll}7.5 \% & 24.4 \% & 41.2 \% & 22.0 \%\end{array}$

$\begin{array}{llll}2.7 \% & 4.4 \% & 12.4 \% & 4.0 \%\end{array}$

$\begin{array}{llll}4.8 \% & 15.6 \% & 29.9 \% & 22.0 \%\end{array}$

$\begin{array}{lll}0.7 \% & 1.3 \% & 6.2 \%\end{array}$

$\begin{array}{lll}1.4 \% & - & 6.2 \%\end{array}$

$\begin{array}{llll}0.7 \% & 0.6 \% & 1.0 \% & 4.0 \%\end{array}$

$\begin{array}{llll}0.7 \% & 1.3 \% & 6.2 \% & -\end{array}$

$\begin{array}{cccc}0.7 \% & 1.9 \% & 4.1 \% & - \\ 1.4 \% & 5.6 \% & 16.5 \% & 4.0 \%\end{array}$

$\begin{array}{llll}8.2 \% & 20.6 \% & 37.1 \% & 6.0 \%\end{array}$

$\begin{array}{llll}6.2 \% & 16.9 \% & 39.2 \% & 18.0 \%\end{array}$

$\begin{array}{llll}14.4 \% & 18.1 \% & 41.2 \% & 14.0 \%\end{array}$

$\begin{array}{llll}2.7 \% & 4.4 \% & 12.4 \% & 6.0 \%\end{array}$

$\begin{array}{llll}5.5 \% & 4.4 \% & 16.5 \% & 10.0 \%\end{array}$

$35.6 \% \quad 49.4 \% \quad 64.9 \% \quad 42.0 \%$

$\begin{array}{llll}2.1 \% & 2.5 \% & 5.2 \% & -\end{array}$

$\begin{array}{llll}0.7 \% & 0.6 \% & 8.2 \% & 2.0 \%\end{array}$

$\begin{array}{llll}- & 1.9 \% & 5.2 \% & 2.0 \%\end{array}$

$11.0 \% \quad 16.9 \% \quad 32.0 \% \quad 18.0 \%$

$2.1 \% \quad 1.9 \% \quad 6.2 \% \quad$ - 
ARACHNIDA (ARACHNIDS)

Araneae (spiders)

Agelenidae

Anyphaenidae

Araneidae

Clubionidae

Corinnidae

Gnaphosidae

Linyphiidae

Lycosidae

Oecobiidae

Oonopidae

Pholcidae

Salticidae

Scytodidae

Theridiidae

Thomisidae

"Acari" (mites)

$\begin{array}{ll}\text { Galumnidae } & \text { armored mites } \\ \text { Ixodidae } & \text { hard ticks } \\ \text { UnID Oribatida } & \text { armored mites } \\ \text { Pyroglyphidae } & \text { dust mites }\end{array}$

Pyroglyphidae

Opiliones (harvestmen \& daddy-longlegs)

Pseudoscorpionida (pseudoscorpions)

\section{CHILOPODA (CENTIPEDES) 42\%}

Lithobiomorpha (stone centipedes)

Lithobiidae

Scolopendromorpha (tropical centipedes)

Scolopendridae tropical centipedes

funnel weavers, grass spiders

ghost spiders

orb weavers

sac spiders

antmimics, ground spiders

ground spiders

sheetweb \& dwarf spiders

wolf spiders

wall spiders

goblin spiders

cellar spiders

jumping spiders

spitting spiders

cobweb spiders

crab spiders

dust mites

stone centipedes

\begin{tabular}{|c|c|c|c|c|c|c|c|}
\hline $100 \%$ & $79.6 \%$ & $47.4 \%$ & $94.4 \%$ & $68.5 \%$ & $78.1 \%$ & $96.9 \%$ & $90.0 \%$ \\
\hline $100 \%$ & $78.5 \%$ & $47.4 \%$ & $92.6 \%$ & $68.5 \%$ & $75.6 \%$ & $96.9 \%$ & $88.0 \%$ \\
\hline $46 \%$ & $8.3 \%$ & $2.6 \%$ & $20.4 \%$ & $2.1 \%$ & $6.9 \%$ & $16.5 \%$ & $6.0 \%$ \\
\hline $30 \%$ & $4.3 \%$ & - & $1.9 \%$ & $0.7 \%$ & $5.6 \%$ & $11.3 \%$ & $4.0 \%$ \\
\hline $18 \%$ & $2.2 \%$ & - & $1.9 \%$ & $1.4 \%$ & $1.3 \%$ & $6.2 \%$ & $2.0 \%$ \\
\hline $10 \%$ & $0.9 \%$ & - & - & - & - & $4.1 \%$ & $2.0 \%$ \\
\hline $38 \%$ & $6.0 \%$ & $5.3 \%$ & $9.3 \%$ & $1.4 \%$ & $6.9 \%$ & $11.3 \%$ & $4.0 \%$ \\
\hline $48 \%$ & $8.1 \%$ & - & $5.6 \%$ & $3.4 \%$ & $10.0 \%$ & $20.6 \%$ & $2.0 \%$ \\
\hline $22 \%$ & $2.9 \%$ & - & $3.7 \%$ & - & $1.3 \%$ & $10.3 \%$ & $2.0 \%$ \\
\hline $40 \%$ & $5.8 \%$ & $2.6 \%$ & $5.6 \%$ & $2.1 \%$ & $2.5 \%$ & $16.5 \%$ & $8.0 \%$ \\
\hline $28 \%$ & $8.8 \%$ & $2.6 \%$ & - & $6.2 \%$ & $10.0 \%$ & $18.6 \%$ & $8.0 \%$ \\
\hline $16 \%$ & $3.2 \%$ & $5.3 \%$ & - & $2.1 \%$ & $3.8 \%$ & $6.2 \%$ & $2.0 \%$ \\
\hline $84 \%$ & $28.0 \%$ & $7.9 \%$ & $38.9 \%$ & $19.2 \%$ & $18.1 \%$ & $56.7 \%$ & $32.0 \%$ \\
\hline $50 \%$ & $8.3 \%$ & $2.6 \%$ & $3.7 \%$ & $2.7 \%$ & $7.5 \%$ & $22.7 \%$ & $6.0 \%$ \\
\hline $16 \%$ & $2.7 \%$ & - & $1.9 \%$ & $3.4 \%$ & $2.5 \%$ & $4.1 \%$ & $2.0 \%$ \\
\hline $100 \%$ & $65.3 \%$ & $39.5 \%$ & $77.8 \%$ & $55.5 \%$ & $61.3 \%$ & $87.6 \%$ & $70.0 \%$ \\
\hline $32 \%$ & $3.4 \%$ & $2.6 \%$ & $1.9 \%$ & - & $4.4 \%$ & $9.3 \%$ & $2.0 \%$ \\
\hline $76 \%$ & $18.6 \%$ & $5.3 \%$ & $46.3 \%$ & $4.8 \%$ & $17.5 \%$ & $36.1 \%$ & $10.0 \%$ \\
\hline $12 \%$ & $1.1 \%$ & - & $1.9 \%$ & - & $0.6 \%$ & $4.1 \%$ & - \\
\hline $18 \%$ & $2.0 \%$ & - & - & $0.7 \%$ & $1.9 \%$ & $7.2 \%$ & - \\
\hline $46 \%$ & $6.0 \%$ & - & $22.2 \%$ & $1.4 \%$ & $3.8 \%$ & $12.4 \%$ & $2.0 \%$ \\
\hline $76 \%$ & NA & NA & NA & NA & NA & NA & NA \\
\hline $16 \%$ & $2.3 \%$ & $2.6 \%$ & $3.7 \%$ & $0.7 \%$ & $2.5 \%$ & $5.2 \%$ & - \\
\hline $20 \%$ & $2.7 \%$ & - & $3.7 \%$ & $0.7 \%$ & $0.6 \%$ & $10.3 \%$ & $2.0 \%$ \\
\hline $42 \%$ & $9.2 \%$ & - & $16.7 \%$ & $4.1 \%$ & $9.4 \%$ & $16.5 \%$ & $10.0 \%$ \\
\hline $18 \%$ & $1.8 \%$ & - & $1.9 \%$ & - & $1.9 \%$ & $5.2 \%$ & $2.0 \%$ \\
\hline $14 \%$ & $1.3 \%$ & - & $1.9 \%$ & - & $1.9 \%$ & $2.1 \%$ & $2.0 \%$ \\
\hline $12 \%$ & $2.2 \%$ & - & $5.6 \%$ & $0.7 \%$ & $1.9 \%$ & $5.2 \%$ & - \\
\hline $12 \%$ & $2.2 \%$ & - & $5.6 \%$ & $0.7 \%$ & $1.9 \%$ & $5.2 \%$ & - \\
\hline
\end{tabular}


Scutigeromorpha (house centipedes)

$$
\text { Scutigeridae house centipedes }
$$

DIPLOPODA (MILLIPEDES)

Callipodida (crested millipedes)

$$
\text { Abacionidae crested millipedes }
$$

Julida (julid millipedes)

$$
\text { Julidae millipedes }
$$

Polydesmida (flat-backed millipedes)

$$
\text { Paradoxosomatidae greenhouse millipedes }
$$$$
\text { Polydesmidae flat-backed millipedes }
$$

Spirobolida (round-backed millipedes)

$$
\text { Spirobolidae }
$$

round-backed millipedes

\begin{tabular}{|c|c|c|c|c|c|c|c|}
\hline $32 \%$ & $6.9 \%$ & - & $13.0 \%$ & $3.4 \%$ & $6.9 \%$ & $10.3 \%$ & $10.0 \%$ \\
\hline $32 \%$ & $6.9 \%$ & - & $13.0 \%$ & $3.4 \%$ & $6.9 \%$ & $10.3 \%$ & $10.0 \%$ \\
\hline $82 \%$ & $21.1 \%$ & $5.3 \%$ & $63.0 \%$ & $6.2 \%$ & $15.0 \%$ & $38.1 \%$ & $16.0 \%$ \\
\hline $10 \%$ & $1.8 \%$ & - & $5.6 \%$ & - & $2.5 \%$ & $3.1 \%$ & - \\
\hline $10 \%$ & $1.8 \%$ & - & $5.6 \%$ & - & $2.5 \%$ & $3.1 \%$ & - \\
\hline $42 \%$ & $4.7 \%$ & - & $18.5 \%$ & $2.1 \%$ & $2.5 \%$ & $9.3 \%$ & - \\
\hline $38 \%$ & $3.8 \%$ & - & $11.1 \%$ & $2.1 \%$ & $2.5 \%$ & $8.2 \%$ & - \\
\hline $72 \%$ & $17.7 \%$ & $5.3 \%$ & $57.4 \%$ & $4.8 \%$ & $13.1 \%$ & $29.9 \%$ & $14.0 \%$ \\
\hline $58 \%$ & $12.6 \%$ & $2.6 \%$ & $42.6 \%$ & $2.7 \%$ & $9.4 \%$ & $22.7 \%$ & $10.0 \%$ \\
\hline $26 \%$ & $4.3 \%$ & - & $16.7 \%$ & $1.4 \%$ & $1.3 \%$ & $8.2 \%$ & $4.0 \%$ \\
\hline $20 \%$ & $2.3 \%$ & - & $14.8 \%$ & $0.7 \%$ & - & $3.1 \%$ & $2.0 \%$ \\
\hline $18 \%$ & $2.2 \%$ & - & $14.8 \%$ & $0.7 \%$ & - & $2.1 \%$ & $2.0 \%$ \\
\hline $86 \%$ & $23.8 \%$ & $5.3 \%$ & $57.4 \%$ & $14.4 \%$ & $20.0 \%$ & $34.0 \%$ & $22.0 \%$ \\
\hline $84 \%$ & $23.6 \%$ & $5.3 \%$ & $57.4 \%$ & $14.4 \%$ & $20.0 \%$ & $34.0 \%$ & $20.0 \%$ \\
\hline $78 \%$ & $22.0 \%$ & $5.3 \%$ & $48.1 \%$ & $13.7 \%$ & $18.8 \%$ & $33.0 \%$ & $20.0 \%$ \\
\hline $20 \%$ & $4.2 \%$ & - & $14.8 \%$ & $1.4 \%$ & $3.8 \%$ & $5.2 \%$ & $4.0 \%$ \\
\hline
\end{tabular}

\section{MALACOSTRACA (CRUSTACEANS)}

Isopoda (isopods)

$$
\text { Armadillidiidae pillbugs \& rolypolies }
$$$$
\text { Porcellionidae }
$$ 